Jpn. J. Med. Sci. Biol., 45, 75 - 80, 1992.

Short Communication

\title{
ASSESSMENT OF THE MOLLUSCICIDAL ACTIVITIES OF TRIBROMOSALAN, CARTAP AND CHLOROTHALONIL AGAINST ONCOMELANIA HUPENSIS
}

Quanbin XIA, Peiping TAN, Xingang FENG, Meili CHEN, Noriaki KAJIHARA1, Masaru MINAI1 and Yukio HOSAKA2

Provincial Research Institute of Parasitic Diseases, Yueyang City, Hunan, China, 1 Yamanashi Prefectural Institute for Public Health, Kofu, Yamanashi 400 and 2 Department of Parasitology, National Institute of Health, Kamiosaki, Shinagawa-ku, Tokyo 141

(Received February 6, 1992. Accepted June 11, 1992)

SUMMARY: Molluscicidal activities of Tribromosalan, Cartap and Chlorothalonil were evaluated in the laboratory and the field against Oncomelania hupensis, the intermediate host of Schistosoma japonicum in China. The three chemicals were very effective against $O$. hupensis in the laboratory. The molluscicidal activities found in the field trials suggest that Tribromosalan and Cartap may be used as practical molluscicides. Dosage of $10 \mathrm{~g} / \mathrm{m}^{2}$ of Tribromosalan in spring only and $20 \mathrm{~g} / \mathrm{m}^{2}$ of Cartap in both spring and autumn would be recommendable as practical mollusciciding doses for the control of $O$. hupensis.

Molluscicidal activities of three chemicals, Tribromosalan $\left(3,4^{\prime}, 5-\right.$ tribromosalicylanilide), Cartap (S,S'-[2-(dimethylamino)-trimethylene] bis (thiocarbamate)) and Chlorothalonil (Tetrachloroisophthalonitrile) against Oncomelania nosophora, the intermediate host of Schistosoma japonicum in

梶原德昭·薬袋 勝 (山梨県衛生公害研究所 甲府市富士見1-7-31)

保阪幸男 (国立予防衛生研究所寄生虫部) 
Table I. Molluscicidal effects of three chemicals on Oncomelania hupensis in the laboratory

\begin{tabular}{|c|c|c|c|}
\hline Chemical & $\begin{array}{l}\text { Season of } \\
\text { snail } \\
\text { collection }\end{array}$ & $\begin{array}{l}\mathrm{LC}_{50} \text { in } \mathrm{ppm}^{*} \\
\text { (95\% confidence } \\
\text { limits) }\end{array}$ & $\begin{array}{l}\mathrm{LC} 90 \text { in } \mathrm{ppm}^{*} \\
\text { (95\% confidence } \\
\text { limits) }\end{array}$ \\
\hline $\begin{array}{l}\text { Tribromo- } \\
\text { salan }\end{array}$ & $\begin{array}{l}\text { Spring } \\
\text { Autumn }\end{array}$ & $\begin{array}{l}0.068(0.059-0.077) \\
0.320(0.280-0.360)\end{array}$ & $0.089(0.078-0.10)$ \\
\hline Cartap & $\begin{array}{l}\text { Spring } \\
\text { Autumn }\end{array}$ & $\begin{array}{l}0.32(0.24-0.41) \\
0.61(0.45-0.82)\end{array}$ & $0.43(0.33-0.56)$ \\
\hline $\begin{array}{l}\text { Chloro- } \\
\text { thalonil }\end{array}$ & Spring & $0.13(0.11-0.15)$ & $0.17(0.15-0.19)$ \\
\hline
\end{tabular}

${ }^{*}$ Concentrations are based on the active ingredient.

Japan, were first reported by Kajihara et al $(1,2)$. They noted high molluscicidal activities of the three chemicals against Oncomelania snails. Tribromosalan is an anthelmintic and Cartap and Chlorothalonil are used as agricultural drugs in Japan. These chemicals are registered as agricultural drugs or anthelmintics and are commercially available.

The present paper deals with the molluscicidal activities of the three chemicals, Tribromosalan, Cartap and Chlorothalonil against $O$. hupensis, the vector snail of schistosomiasis in China. The results of field trials with the three chemicals are also presented.

$O$. hupensis snails used for the laboratory experiments were collected from Junshan Isle, Yueyang, China and were conditioned in the laboratory for two weeks. To bring the snails in contact with the chemicals, Komiya's immersion technique (3) was adopted. Thirty snails were exposed to each of consecutive twofold dilutions of each chemical at 24-26 C for $48 \mathrm{hr}$. Duplicate or triplicate tests were carried out with each chemical and $\mathrm{LC}_{50}$ and $\mathrm{LC}_{90}$ (50\% and $90 \%$ lethal concentrations, respectively) were computed. Table I shows the results based on the concentration of the active ingredient of the chemicals. The $\mathrm{LC}_{50}$ values of Tribromosalan and Cartap varied with the season of snail collection, however, the molluscicidal effects of the chemicals on $O$. hupensis were high. The 
Table II. $\mathrm{LC}_{50}$ values of Tribromosalan, Cartap, Chlorothalonil and B-2 (Phebrol) against Oncomelania snails determined in the laboratory

\begin{tabular}{lclll}
\hline Snail & Chemical & $\begin{array}{l}\text { Season of } \\
\text { snail } \\
\text { collection }\end{array}$ & LC $_{50}(\mathrm{ppm})^{*}$ & Reference \\
\hline O. hupensis & Tribromo- & Spring & 0.068 & \\
& salan & Autumn & 0.320 & \\
& Cartap & Spring & 0.32 & \\
& Autumn & 0.61 & \\
& Chloro- & Spring & 0.13 & \\
& thalonil & & & \\
& B-2 & Spring & 0.38 & $(4)$ \\
& Tribromo- & Spring & 0.068 & $(2)$ \\
& salan & Autumn & 0.350 & \\
& Cartap & Spring & 0.42 & $(2)$ \\
& & Autumn & 0.36 & \\
& Chloro- & Spring & 0.14 & $(1)$ \\
& thalonil & & & \\
& B-2 & Spring & 0.38 & $(5)$ \\
& & Autumn & 0.65 & \\
\hline
\end{tabular}

${ }^{*}$ Concentrations are based on the active ingredient.

molluscicidal activity of Tribromosalan was higher than that of Chlorotharonil. The activity of Cartap seemed to be lower than those of Tribromosalan and Chlorothalonil. The $\mathrm{LC}_{50}$ values of the three chemicals and B-2 (Phebrol) against $O$. hupensis (4) and $O$. nosophora (5) are shown in Table $\mathrm{II}$. The $\mathrm{LC}_{50}$ value of each chemical against $O$. hupensis was almost equal to that of each against $O$. nosophora. B-2 is known to be effective in the control of Oncomelania snails and commonly used as a molluscicide in Japan (4-6). The molluscicidal activities of Tribromosalan, Cartap and Chlorothalonil against $O$. hupensis appeared to be similar to or higher than that of B-2 in the laboratory. Yasuraoka et al. (7) noticed that the susceptibility of $O$. nosophora to molluscicides varied with the season of the year and that the snail susceptibility increased in spring and 
Table III. Molluscicidal effects of three chemicals against Oncomelania hupensis in the field

\begin{tabular}{|c|c|c|c|}
\hline Chemical & $\begin{array}{l}\text { Dose } \\
\left(\mathrm{g} / \mathrm{m}^{2}\right)\end{array}$ & $\begin{array}{c}\text { Mean mortality } \\
\text { after chemical a } \\
\text { Spring }\end{array}$ & $\begin{array}{l}\text { n } 7 \text { and } 14 \text { days } \\
\text { Autumn }\end{array}$ \\
\hline $\begin{array}{l}\text { Tribromo- } \\
\text { salan }\end{array}$ & $\begin{array}{r}5 \\
10 \\
20\end{array}$ & $\begin{array}{l}85.5(\%) \\
90.6 \\
92.2\end{array}$ & $\begin{array}{l}27.7(\%) \\
29.5 \\
41.7\end{array}$ \\
\hline Cartap & $\begin{array}{r}5 \\
10 \\
20\end{array}$ & $\begin{array}{l}49.0 \\
72.3 \\
83.1\end{array}$ & $\begin{array}{l}46.9 \\
71.5 \\
89.1\end{array}$ \\
\hline $\begin{array}{l}\text { Chloro- } \\
\text { thalonil }\end{array}$ & $\begin{array}{r}5 \\
10 \\
20\end{array}$ & $\begin{array}{l}36.1 \\
46.8 \\
52.5\end{array}$ & $\begin{array}{l}13.2 \\
14.9 \\
22.8\end{array}$ \\
\hline
\end{tabular}

decreased in autumn. The results obtained in the present study on the seasonal variation of the susceptibility of $O$. hupensis to the chemicals were similar to those found with $O$. nosophora. Attention should be paid to the seasonal variation of the susceptibility of snails in evaluating the molluscicidal activity of any chemical.

Field trials were performed in two localities, Junshan Isle and Chuengfeng Farm, Hunan Province, in China. To find the seasonal variation of the susceptibility of snails, three chemicals were tested in the field twice a year, in spring and in autumn. Sixteen quadrates each of $6 \mathrm{~m}^{2}$ were made in each snail habitat. The quadrate was surrounded with a man-made canal and the grass was mowed to about $5 \mathrm{~cm}$ before chemical application. The active ingredients of Tribromosalan, Cartap and Chlorothalonil were 90, 50 and 75\%, respectively. Each chemical was suspended in water and sprayed with a handy sprayer in each quadrate at a dose of 2.5 to $40 \mathrm{~g}$ of consecutive twofold dose per square meter. Post-treatment samplings of the snail were made in either 3, 7 and 14 days or 7 , 14 and 21 days after application of the chemical. The results of the field trials are summarized in Table III. The mortalities of snails in the quadrate treated with Tribromosalan in spring were higher than $85 \%$ : in autumn, the rates were lower 
than $42 \%$. The treatment with Cartap at a dose of $20 \mathrm{~g} / \mathrm{m}^{2}$ showed a snail mortality rate higher than $83 \%$ regardless of the season. The treatment with Chlorothalonil resulted in low mortalities of snails, lower than 53\%, even in the quadrate applied with $20 \mathrm{~g} / \mathrm{m}^{2}$ of the chemical. From the results of the field trials, the doses of $20 \mathrm{~g} / \mathrm{m}^{2}$ of Cartap both in spring and autumn and $10 \mathrm{~g} / \mathrm{m}^{2}$ of Tribromosalan in spring only would be recommendable as practical mollusciciding doses for the control of $O$. hupensis in China.

As mentioned above, B-2 is known to be an effective molluscicide in the control of Oncomelania snails and is applicable to the rice paddy-field without causing any disadvantageous problems for the environment $(6,8)$. The molluscicidal activities of Tribromosalan and Cartap against $O$. hupensis appeared to be similar to that of B-2. These chemicals have satisfied the safety standards and are registered as agricultural drugs or anthelmintics in Japan. Tribromosalan and Cartap may be used as practical molluscicides in the control of O. hupensis without serious environmental pollution.

\section{ACKNOWLEDGEMENTS}

The authors are indebted to Fujita Pharmaceutical Co. Ltd. and Takeda Chemical Industries Ltd. for supplying the chemicals.

\section{REFERENCES}

1. Kajihara, N. and Minai, M. (1986): The molluscicidal effects of agricultural chemicals and anthelmintics on Oncomelania nosophora. Jpn. J. Parasitol., 35, 124 (Suppl.), (in Japanese).

2. Kajihara, N., Minai, M. and Satoh, Y. (1987): A screening test for the molluscicidal activity of chemicals against Oncomelania nosophora. Annu. Rep. Yamanashi Prefect. Inst. Publ. Hlth. 30, 31-38 (in Japanese).

3. Komiya, Y., Hosaka, Y. and Yasuraoka, K. (1962): Study for the standardization of quantitative test of the susceptibility of Oncomelania snails to sodium pentachlorophenate. Jpn. J. Med. Sci. Biol., 15, 41-51.

4. Wong, M. K., Xia, Q. B., Chen, M. L., Zhang, C. X., Mao, P. S., Nei, G. Q. and Hosaka, Y. (1988): Laboratory and field assessment of molluscicidal activity of B-2 against Oncomelania hupensis, the vector snail of schistosomiasis in China. Jpn. J. Med. Sci. Biol., 41, 31-36. 
5. Kajihara, N., Horimi, T., Minai, M. and Hosaka, Y. (1979): Laboratory assessment of the molluscicidal activity of B-2, a new chemical against Oncomelania nosophora. Jpn. J. Med. Sci. Biol., 32, 185-188.

6. Kajihara, N., Horimi, T., Minai, M. and Hosaka, Y. (1979): Field assessment of B-2 as a new molluscicide for the control of Oncomelania nosophora. Jpn. J. Med. Sci. Biol., 32, 225-228.

7. Yasuraoka, K., Hosaka, Y. and Komiya, Y. (1966): Seasonal variation in the susceptibility of Oncomelania nosophora to sodium pentachlorophenate in relation to bioassay of molluscicides. Jpn. J. Med. Sci. Biol., 19, 105-107.

8. Hosaka, Y., Hashiguchi, J., Sakata, Y., Banez, E. A. and Blas, B. L. (1984): An assessment of the molluscicidal activity of B-2 and some other chemicals against Oncomelania quadrasi. Jpn. J. Parasitol., 33, 55-58. 